\title{
STE DEJALI IZOBRAŽEVANJE STAREJŠIH ODRASLIH, STE DEJALI DEJAVNA POZNEJŠA LETA ŽIVLJENJA?
}

$U$ vodoma se vprašajmo, koga sploh imamo $v$ mislih, ko pravimo starejši odrasli. Priznajte, da ste nehote pomislili predvsem na ljudi $v$ visoki starosti, morda $v$ stanju odvisnosti in $v$ dolgotrajni, najpogosteje institucionalni oskrbi. ${ }^{1}$ Vendar imamo andragogi, ko govorimo o starejših, v mislih veliko skupino ljudi v poznejših letih življenja, ki jo sestavljajo ljudje različne starosti, predvsem pa je njihov položaj $v$ družbi močno različen: starejši delavci od 45. leta dalje, ljudje, ki razmišljajo o skorajšnji upokojitvi in se pripravljajo nanjo, ljudje v tretjem življenjskem obdobju, ki je danes močno drugačno od tistega, ki smo ga poznali nekoč, saj je odvisno od dinamike vključevanja in izključevanja s trga dela, ljudje v četrtem življenjskem obdobju, ki je lahko zelo kratko in traja komaj nekaj let ali pa sploh nikoli ne nastopi. Vse te in druge skupine starejših potrebujejo različno izobraževanje.

Leta 1952 se je v nekaterih zahodnoevropskih državah prvič pojavila potreba po občinskih celostnih politikah starosti in staranja. Ta potreba je mnoge presenetila, saj so se takrat, v povojnem času, v Evropi ukvarjali predvsem z obnovo in prihodnostjo, torej z mladimi. Prvič so se zavedli, da obstaja tudi veliko starejših, prvič so začeli razmišljati o tem, kaj starejši potrebujejo, prvič so ugotovili, da ti potrebujejo več kot tisto, kar so jim ponujali že na začetku 20. stoletja: socialno varnost in javno skrb za zdravje. Kasneje, ko se je pojavilo vprašanje prostega časa, ki se je oglasilo na vrhuncu industrijskega razvoja sredi 70. let preteklega stoletja, je prišlo do znanstvene in politične obravnave prostega časa in tedaj so vlade $v$ zahodnoevropskih
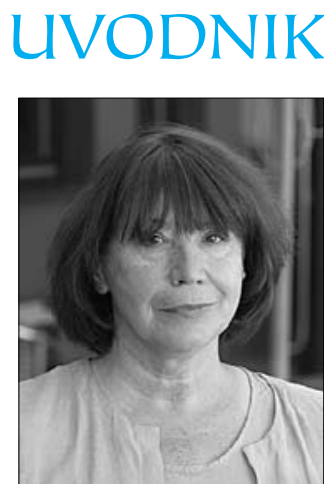

državah začele razmišljati tudi o načinu življenja starejših, saj naj bi bilo njihovo življenje vseskozi en sam prosti čas. To je bil čas, ko so se države z uvajanjem dopolnilnega zasebnega pokojninskega sistema deloma razbremenile skrbi za pokojnine in tedaj so se, dokaj značilno, začele zanimati tudi za oblike in načine življenja starejših. Tako so dale večji poudarek prostočasnim, kulturnim, izobraževalnim in drugim vsebinam življenja starejših. In tako so se pojavili klubi upokojencev, univerze prostega časa, univerze za tretje življenjsko obdobje. ${ }^{2}$

Celostna politika starosti in staranja se naslanja na različne politike (socialno, zdravstveno, urbano, kmetijsko, kulturno, izobraževalno, itn.), ki obravnavajo vprašanja starejših. Preučevanje politike izobraževanja starejših odraslih se je začelo pri besedilih, ki se nanašajo po eni strani na neko ideologijo in po drugi strani na delovanje institucij in organizacij. Vendar preučevati zgolj takšna besedila in zgolj delovanje institucij ni dovolj! Če hočemo govoriti o politiki izobraževanja starejših odraslih, moramo spregovoriti tudi o starejših in o starosti. Le tako dobimo predmet preučevanja, ki se nam zlahka izmuzne, kadar govorimo o politiki in političnih odločitvah ter iz tega izhajajočih zakonih in pravnih dokumentih. In kaj je izobraževalna politika na področju starejših? Nič drugega kot družbeni konstrukt celote praks in reprezentacij, ki tvorijo družbeno dejstvo starejših in starosti.

Analiza politike izobraževanja starejših odraslih ne pojasni pravnih in upravnih ukrepov ter 
njihovih posledic, marveč nam omogoča, da razumemo, kako človeška skupnost v današnjem času liberalizma uporablja svojo najdragocenejšo dobrino: človeško življenje, ki teče od »zibelke do groba«, in kako uporablja dobrino starejšega človeka. Ali ceni, ohranja ali morebiti celo razvija razvojne možnosti starejših? Ali pa jih nemara pušča $v$ vnemar in jih celo zatira?

\section{IZOBRAŽEVANJE STAREJŠIH ODRASLIH ZRCALI OSEBNE PA TUDI DRUŽBENE POTREBE}

Ob pisanju tega uvodnika mi je prišlo na misel, kako drugačen od današnjega bi bil ta uvodnik pred tridesetimi, dvajsetimi, desetimi leti. Vzrokov, da se posamezna obdobja med seboj nedvomno razlikujejo, je veliko, zlasti zato, ker je prizadevanje geragogov, andragogov in strokovnjakov za izobraževanje starejsih odraslih zmeraj odvisno od znanja, ki ga ti imajo na neki stopnji svojega strokovnega in poklicnega razvoja, predvsem pa od družbenega ozračja in družbenih sprememb, ki so že tu ali se morda komaj sluteno napovedujejo. Slednje namreč pomembno določajo izobraževalne potrebe starejših samih in vseh, ki s starejšimi živimo ${ }^{3}$ ali z njimi delamo.

Izobraževanje starejših odraslih tako zrcali osebne potrebe starejših (nove socialne vloge, nova stopnja $v$ razvoju družine, obvladovanje sprememb pred, med ali po življenjskih prelomnicah, kratkoročni ali dolgoročni načrti, kognitivne, emocionalne, socialne potrebe in potrebe po vrednotah ipd.). Toda, izobraževanje starejših je tudi izobraževanje obrobne družbene skupine - kljub velikemu številu starejših je družbeni položaj ljudi v poznejših letih življenja, kot starejšse imenujemo danes, še zmeraj obroben - sleherno izobraževanje obrobnih družbenih skupin pa ni le prenašanje znanja ali ustvarjanje novega znanja $z$ recipročnim, vzajemnim, sodelovalnim, transformativnim učenjem odraslih, je tudi hkratno izobraževanje za pridobivanje psihološke, ekonomske, družbene in politične moči. To pomeni, da morajo mentorji starejših odraslih poleg svoje vede poznati tudi temeljne gerontološke, geragoške pa tudi psihološke, sociološke, filozofske, ekonomske in druge koncepte, ki pomagajo razumeti starejše ljudi in jih krepiti. Skratka, izobraževanje starejših je odgovor na osebne potrebe starejših odraslih, pri tem pa zrcali stanje družbe ali napoveduje družbene spremembe. Teh pa je bilo $v$ zadnjih desetletjih veliko, tako $v$ nacionalnem kot $v$ internacionalnem, evropskem prostoru. ${ }^{4}$

Pred tremi desetletji, v času, ko sta si bila kultura in izobraževanje vsaksebi, bi nedvomno pisala, ali bi pisali, predvsem o kulturi v izobraževanju starejših, danes pišemo predvsem o potrebi ohranjanja in razvoja nesnovne kulturne dediščine starejših, o njenem vključevanju v organizirano prostovoljno delo kulturnih mediatorjev $v$ slovenskih muzejih, o izobraževanju starejših in muzejskega osebja za takšen prenos dediščine.

$V$ času usmerjenega izobraževanja, poudarjanja kolektivizma bi, oziroma smo, pisali o tem, da naj bo izobraževanje osredotočeno na starejšega učenca; na njegove potrebe, zanimanje, na potrebo, da si z učenjem $v$ majhni študijski skupini, izobraževanjem in kulturo gradi svojo družbeno vrednost. Pisala bi tudi o pravici starejših, da živijo nepretrgan krog življenja, da ne pristanejo na to, da jim drugi določajo, do kod (in do kdaj) smejo seči njihove kognitivne, emocionalne, socialne in druge potrebe. Že takrat sem nejasno slutila to, kar danes vem: kronološka starost je od vseh možnih določil tisto najmanj pomembno določilo posameznika ali generacije. Tega se še posebno zavedamo, kadar načrtujemo, organiziramo ali izvajamo medgeneracijsko izobraževanje.

Posameznika ali generacijo in izobraževanje zanj ali zanjo namreč pomembno določajo 
povsem druge reči in te druge reči moramo poznati, kadar organiziramo, načrtujemo in izvajamo izobraževanje za ljudi v poznejših letih življenja. Tako je pomembno vedeti, ali je nekdo zaposlen ali ne, ali dela prostovoljno ali ne, ali živi s partnerjem ali ne, ali ima družino ali ne, ali je ženska ali je moški, ali ga družina v izobraževanju podpira ali ne, ali je dobrega ali slabšega zdravja, pomembno je poznati njegove ali njene pretekle, zdajšnje in prihodnje socialne vloge, njegove ali njene dolgoročne načrte, njegovo ali njeno izkustveno znanje. Ta in druga določila (kronološka starost pa prav malo) določajo izobraževalne potrebe ljudi v poznejših letih življenja. ${ }^{5}$

Nemalokrat sem $v$ domala tridesetih letih dela na področju izobraževanja starejših naletela na trdovratne stereotipe o starejših in o učenju ter izobraževanju starejših. »Kako pa delate s starejšimi, gotovo morate bolj tako, po otročje, " mi je nekoč dejala sicer dobronamerna mlada novinarka. Ti, ki naj bi se učili tako, »bolj po otročje«, pa so tik pred tem zapustili mesto primarija, direktorja velikega podjetja, delovno mesto razvojnega tehnologa. »Gospod, gospa zakaj se učite pri vaših letih? «se je glasilo ponavljajoče se vprašanje mladega novinarja dvajset let kasneje. »Vse življenje sem se moral učiti za delo, poklic, zdaj sem si vzel pravico, da se učim za življenje." »Učim se zato, ker delam z mladimi, da jih bolje razumem. « «čim se, ker je to danes potrebno. « »Učim se zato, ker se učim že celo življenje in si življenja brez učenja ne predstavljam," so se vrstili odgovori. »Vsi nas sprašujejo, zakaj: prijatelji, znanci, novinarji, « so govorili moji prvi starejši udeleženci izobraževanja. Vprašanje motivov starejših za izobraževanje je bilo neprestano $v$ zraku, kot da je nenavadno, da se starejši želijo učiti. Tako je bilo na začetku. Danes pa, komaj pred nekaj dnevi, dolg intervju s kolegico z Univerze za tretje življenjsko obdobje, novinarjeva nepozornost in velik naslov v časopisu »Starostniki si želijo vse več znanja, ne želijo več sedeti za zapečkom«. Vrh tega pa še slikovna oprema, podoba starih žensk, ki oblikujejo cvetje iz papirja. Značilna podoba naključnega prostega časa, kakršno družba starejšim dopušča, s politiko podpira in omogoča, dejavnost, ki v nasprotju $z$ resno obliko namenskega preživljanja prostega časa, kot je denimo izobraževanje, ne pušča posledic za posameznika in družbo. ${ }^{6}$ Kaj storiti proti tem stereotipom?

Stereotipi o starejših pa ne krožijo le med ljudmi, marveč tudi med strokovnjaki vseh vrst in politiki $v$ nacionalnem in tudi internacionalnem prostoru. Kot evropska izvedenka za zaposlovanje in izobraževanje starejših se pogosto udeležujem tematskih konferenc in »peer reviews « evropske komisije, ki obravnavajo prebivalstvene spremembe, proizvodno starost, staranje delovne sile, dejavno staranje itn. Včasih sem tudi povabljena na delovno kosilo s kadrovskimi direktorji velikih družb, kot je denimo Air France, ki v svojih podjetjih razmišljajo o »privlačnosti dela in delovnih mest«, o »upravljanju starosti in znanja«. Izobražujem ali svetujem delodajalcem, ki so sicer pripravljeni zaposliti starejše delavce, a »ne starejših od sebe«, itn. Preučujem zakonodajo in odkrivam $v$ določilih zakona skrite načine prisilnega in »ex lege« upokojevanja, neenako obravnavo zaposlenih in samozaposlenih pri upokojevanju in delu, ki je tudi oblika prisilnega upokojevanja, onemogočanje dejavnega staranja. Kulturni in uzakonjeni stereotipi, znova stereotipi in omejitve! Tudi v nekaterih nevladnih organizacijah, celo tistih, ki se ukvarjajo s starejšimi, prežijo na nas stereotipi o starejših. Slabo prikrit odpor do dela, prostovoljnega dela upokojenih starejših. To naj bi bilo manj strokovno, ti naj bi bili manj zanesljivi, manj delovni itn. Odkrivanje in obravnava stereotipov o poznejših letih življenja sta pogost predmet izobraževanja. Kritična geragogika sicer ni priljubljena, je pa potrebna in veljalo bi jo vključiti tudi v predmetnik 
visokošolskega študija geragogike, ki se bo neizogibno razvil tudi $v$ Sloveniji. Vse nas bo namreč sililo $v$ to, da ga postavimo na noge, da damo prostor raziskovanju izobraževanja starejših odraslih in širših učinkov njihovega učenja ter drugih vprašanj.

$V$ starajoči se družbi se tako vse postavi na glavo, ne le starostna piramida, tudi pojmovanje starosti in staranja, tako kot se na glavo postavijo tudi razmerja med generacijami. Dobro bi bilo, da bi se to zgodilo čim bolj evolutivno, s čim manj pretresov, ob čim boljšem poznavanju značilnosti - podobnosti in razlik - posameznih generacij. Pri tem je pomembno, da damo znanju starejših prav takšno veljavo, kot jo dajemo znanju mladih in srednje starih, kajti znanje je socialno dejstvo, ki se gradi in plemeniti v skupnosti in tako vrača vsem. Če kateri koli družbeni skupini odrečemo izobraževanje, s tem povečujemo neukost vseh.

\section{KDO SO DANES NOSILCI IZOBRAŽEVANJA STAREJŠIH ODRASLIH}

$V$ slovenskem prostoru so pred tremi desetletji mnogi izobraževanje odraslih istovetili $z$ izobraževanjem starejših. Izobraževanje za tretje življenjsko obdobje je tako za mnoge postalo sopomenka izobraževanja odraslih.

Univerza za tretje življenjsko obdobje je leta 1984 postala prvi večji poskus demokratizacije izobraževanja odraslih. Iz pretežno izobraževanja za delo in »second chance«, političnega in jezikovnega, izobraževanja smo se z Univerzo za tretje življenjsko obdobje začeli preusmerjati $v$ izobraževanje za življenje. Iz nenehnega opazovanja in raziskovanja inducirane prakse izobraževanja starejših sta zlagoma rasli praksa in tudi naša teorija izobraževanja starejših, predvsem tistih $v$ tretjem življenjskem obdobju. Danes Univerza za tretje življenjsko obdobje ni več edina nosilka izobraževanja starejših odraslih.
Pridružili so se ji Inštitut Antona Trstenjaka, stanovska društva, društva upokojencev, centri za socialno delo, knjižnice, ljudske univer$z e$, dnevni centri za starejše, domovi starejših, muzeji. Raznolikost nosilcev zrcali raznolikost potreb in prinaša za izobraževalce pomembno spoznanje; starejši niso homogena skupina. Niso homogena skupina učencev, niso homogena skupina volilcev, niso homogena skupina potrošnikov. Potrebujejo svoj slog življenja in izobraževanja. Imajo svoje učne sloge.

\section{ZAKAJ IN KAKO NAPREJ}

$V$ storilnostno naravnani družbi, kot je današnja, ob dejstvu, da pokojninske reforme navajajo starejše na družbeno solidarnost in $d a$ delajo dlje, je pomembno vedeti, kako bodo starejši, ki prenehajo biti poklicno dejavni, ki izstopajo s trga dela, ostajajo na trgu dela in znova vstopajo nanj, četudi občasno, vstopili $v$ izobraževanje in kakšno naj bo to izobraževanje še posebno $v$ dolgem obdobju dinamike vključevanja in izključevanja na trgu dela. Gre za obdobje, ki ga danes imenujemo »med delom, izobraževanjem in starostjo«. Tako je pomembno vedeti, kako kot pravico iz dela zagotoviti izobraževanje starejših delavcev, predupokojitveno izobraževanje, kako zagotoviti izobraževanje za zaposlitev in delo, osebnostno rast, prostovoljno delo v družbi. Pomembno je vedeti, $s$ katerim znanjem in kako bomo omogočili dejavno staranje in višjo stopnjo sodelovanja starejših v družbi. ${ }^{7}$ Pri teh prizadevanjih imajo lokalne, nacionalne in evropske politike pomembno vlogo.

Izobraževanje ne bi smelo biti polje polarizacije prebivalstva na tiste, ki smejo in zmorejo, in tiste, ki ne smejo in ne zmorejo, kajti to bi imelo hude posledice za vso družbo. Med gospodarskim stanjem, ki se (lahko) izboljšuje, in družbeno stvarnostjo je prepad vse večji. Če želimo doseči trdno in povezano družbo, bi veljalo razmišljati o vpletenosti vseh gene- 
racij in raznolikih družbenih skupin $v$ družbo. $V$ primeru skupine starejših se zavedamo, da je zaradi velikega števila starejših vprašanje starejših, njihovega življenja ter dela v poznejših letih življenja nevralgična točka različnih sistemov, tudi izobraževalnega.

Še več, v starajoči se družbi potrebujemo učinkovit izobraževalni sistem, formalno in neformalno izobraževanje za vse generacije, pri čemer je razumljivo, da je dejavna vloga države v prvem in drugem življenjskem obdobju močnejša kot v primeru odraslih v poznejših letih življenja, ko s podporo države, pokrajine, občin vlogo izobraževalcev ljudi v poznejših letih življenja prevzamejo podjetja in zasebne ustanove, najpogosteje pa organizacije civilne družbe.

\section{Dušana Findeisen}

1 "Danes je dan starejših. Ob desetih se bomo pogovarjali o demenci, "je zadonelo iz nacionalnega radia.

2 V svojem izjemno analitičnem delu "Upad socialnosti« francoska raziskovalka Anne-Marie Guillard analizira socialne politike - in politika starosti in staranja je njihova nevralgična točka - v štirih preteklih desetletij, njihov vzpon in padec. Skozi njeno delo bolje razumemo, kako neka družba konstruira ali znova konstruira starost, kako določa meje, starostna obdobja in smisel žioljenjskim obdobjem.

3 Na Univerzi za tretje življenjsko obdobje začenjamo program Moji starši so stari: kako razumeti potrebe ostarelih staršev in sorodnikov in svoje lastne potrebe $v$ odnosu z njimi.

4 Vprašanja starejših so zdaj v središču pozornosti $v$ evropskem prostoru. Pozornost so sprožili prebivalstvene spremembe, skrb za trajno uravnovešenje javnih financ pa tudi slutnja, da stari kulturni model organizacije starostnih obdobij ne ustreza več in ga je zato treba spremeniti, s tem pa tudi razmerja moči med generacijami.

5 Glej Ianusove smernice za učenje in priporočila za doseganje standardov kakovosti v izobraževanju starejših odraslih (Bfi Steiermark, Graz in Slovenska univerza za tretje življenjsko obdobje, Ljubljana, v tisku).

6 Naključne oblike preživljanja prostega časa se zdijo bolj razširjenje in priljubljene kot oblike resnega preživljanja prostega časa. Toda oblike resnega preživljanja prostega časa omogočajo, da nekdo preseže samega sebe, da se potrdi. "Resni prosti čas « razvije občutek za upravljanje s samim seboj in omogoči napredovanje ter boljšo integracijo $v$ skupnost in tako prispeva $k$ stabilnosti in skladnosti družbe. Če povzamemo, oblike resnega preživljanja prostega časa omogočajo kulturno in moralno potrditev skupnosti, sredi katere se nekdo lahko prepozna kot pripadajoči član družbe.

7 V Grundtvigovem projektu AESAEC, ki ga koordinira Auxilium iz Gradca pravkar nastaja priročnik kot temelj izobraževanja starejših odraslih o evropskih integracijskih procesih, evropskih institucijah in velikih nevladnih organizacijah, pogodbah, skupnih politikah, o tem, kako napisati evropski projekt in ga voditi, ter o vprašanjih starejših. Projekt naj bi omogočil boljše sodelovanje starejših v procesih odločanja na različnih ravneh. 